\title{
Which organisational changes are most beneficial for firm innovation?
}

\author{
Jane Bourke • Frank Crowley* \\ University College Cork, Cork University Business School, Department of Economics, Ireland
}

Received: 4 July 2016

Revised: 19 October 2016

Accepted: 24 October 2016

\begin{abstract}
This paper identifies which types of organisational HRM changes are most beneficial for firm innovation by using a treatment effects analysis and a large dataset of firms from emerging economies. The paper finds that organisational changes have a positive disruptive effect on firm innovation outcomes. However, there is an organisational change hierarchy - where some HRM practices are more important than others. HRM practices that involve engaging with external partners, via collaboration and outsourcing, have the largest effect on innovation outcomes.
\end{abstract}

Keywords: organisational HRM changes; innovation; treatment effects.

JEL Classification Codes: 031, 032.

\section{Introduction}

Successful management of change is crucial to any organisation in order to survive and succeed in the highly competitive and continuously evolving business environment (Todnem By 2005) and the ability of firms to maximise their innovative potential is fundamental to economic growth (Romer 1990). In this paper, we identify which organisational human resource management (HRM) changes are most beneficial for firm innovation.

Examinations of the innovation process, while by no means complete, are extensive. Firm characteristics, such as size, sector, ownership, and location, R\&D investment and engaging with external knowledge sources have all been identified as influential drivers of innovation activity (Mansury and Love 2008; Gordon and McCann 2005; Love, Roper, and Du 2009; Roper, Hewitt-Dundas, and Love 2004). More recently, scholars have reported that human resource management $(\mathrm{HRM})$ practices benefit firm innovation performance (Tether et al. 2005; Toner 2011; Combs et al. 2006; Guest 2011), with increasing evidence of the benefits to firms when HRM practices are applied together (Crowley and Bourke 2016; Laursen and Foss

\footnotetext{
*E-mail: frank.crowley@ucc.ie.

Citation: Bourke, J. and Crowley, F. (2016) Which organisational changes are most beneficial for firm innovation?, Economics and Business Letters, 5(4), 152-158.
} 
2003). Notably, there is limited evidence on HRM practices and innovation in emerging economies (Bourke and Crowley, 2015).

Innovation is a collective process of idea generation and implementation that builds upon resources, skills, and personnel within firms (Gibson and Gibbs 2006). The importance of information sharing and knowledge sourcing activities is well documented in the innovation literature (He and Wong 2012; Love, Roper, and Bryson 2011). Firms can introduce and/or change management structures to facilitate inter-departmental and external collaborations which have been shown to positively influence innovation performance (Cuijpers, Guenter, and Hussinger 2011; He and Wong 2012). Firms may also introduce practices which delegate decision-making authority and responsibility down the hierarchy and facilitate employee participation through upward feedback mechanisms (Subramony 2009). Arundel et al., (2007) report that firms which support high levels of discretion in solving complex problems tend to be more innovation-active. Heterogeneity in decision making and problem solving styles relieves information-processing bottlenecks (Mendelson and Pillai 1999), produces better decisions through the operation of a wider range of perspectives and a more thorough analysis of issues (Richard 2000). New HRM practices might encompass general production or supply operations such as the introduction of advanced manufacturing technologies or quality management systems which have been shown to influence innovation performance (Abrunhosa and Moura E Sá 2008; Santos-Vijande and Álvarez-González 2007; Hewitt-Dundas 2004). In addition, firms may take a strategic approach to outsourcing, obtaining economies of scope within the innovation process (Love and Roper 2001). ${ }^{1}$

By and large, a positive relationship between HRM practices and innovation outcomes (Tether et al. 2005; Toner 2011; Combs et al. 2006; Guest 2011; Laursen and Foss 2003; Bourke and Crowley 2015; Crowley and Bourke 2016; Laursen, Mahnke, and Vejrup-Hansen 2005; Arundel et al 2007) has been reported; and the evidence suggests complementarity between HR practices and therefore the value of 'bundling' of different practices. Introducing such 'bundles' or 'systems' of HRM practices has a positive disruptive effect on firm performance, but which type of HRM practice has the greater effect in terms of innovation outcomes? If a firm is planning to introduce organisational change, where should their energies lie? Is it in introducing practices which empower staff, or encouraging collaboration with external partners, or is it by outsourcing certain activities? This paper fills this gap by assessing the impact of six organisational HRM changes on firm innovation using the fifth Business Environment and Enterprise Performance Survey (BEEPS) and a treatment effects analysis. The key contribution of this paper is the identification of the types of HRM practices which are of most benefit to firms in their quest for innovation success and sustainable competitive advantage.

\section{Data}

The data is from the fifth Business Environment and Enterprise Performance Survey from 2013 (BEEPS). There are 14,939 observations used for this analysis from 30 emerging economies. BEEPS is particularly useful for investigating the type of questions being studied in this paper as it is rich in organisational HRM change indicators, firm descriptive indicators, innovation performance indicators and business geographic environment indicators. Mean statistics of the innovation outcomes, the different HRM practices and firm characteristics are presented in Table 1. 21 per cent of firms across the emerging economies introduced an organisational change over the previous three years. The survey further relays what types of new or significantly changed organisational changes have been implemented for the first time at the

\footnotetext{
${ }^{1}$ It should be noted that not all HRM practices positively influence innovation in firms. For instance, practices which may be associated with a lack of employer commitment to job security, such as short-term and temporary contracts, have been found to be negatively correlated with firm innovation (Michie and Sheehan 2003).
} 
level of the firm. Most organisational HRM changes are introduced by at least 1 in 10 ten firms in the last three years, with 14 and $15 \%$ respectively introducing new knowledge management systems and new methods for distributing responsibilities. However, only $6 \%$ of firms introduced outsourcing or subcontracting of business activities in production, procurement, distribution, recruiting or ancillary services. The next section provides the empirical model to explore which organisational changes produced the largest (or smallest) treatment effects on the likelihood of a firm introducing a new to firm product innovation $(\mathrm{NtF})$ and new to market product innovation $(\mathrm{NtM})$.

Table 1. Descriptive Statistics of Firm Characteristics by Organisational HRM Changes

\begin{tabular}{|c|c|c|}
\hline Variable & Mean & Std. Dev. \\
\hline \multicolumn{3}{|l|}{ Innovation Outcomes } \\
\hline New to Firm Innovation (NtF) & 0.24 & 0.43 \\
\hline New to Market Innovation (NtM) & 0.17 & 0.37 \\
\hline \multicolumn{3}{|l|}{ Organisational HRM Change (OHRM) } \\
\hline Organisational Innovation & 0.21 & 0.41 \\
\hline OHRM1 (New knowledge management systems) & 0.14 & 0.34 \\
\hline OHRM2 (Management systems for general production) & 0.12 & 0.32 \\
\hline OHRM3 (New methods for distributing responsibilities) & 0.15 & 0.35 \\
\hline OHRM4 (Changes in management structures) & 0.10 & 0.29 \\
\hline OHRM5 (New types of collaborations) & 0.10 & 0.30 \\
\hline OHRM6 (Outsourcing or subcontracting) & 0.06 & 0.24 \\
\hline Diversity of Organisational HRM Changes (0-100\%) & 11.17 & 24.79 \\
\hline \multicolumn{3}{|l|}{ Control Variables } \\
\hline R\&D active (spending on $R \& D)$ & 0.11 & 0.31 \\
\hline University Education (percentage) & 34.09 & 31.37 \\
\hline Small Firm (1-19 employees) & 53.23 & 49.89 \\
\hline Medium Firm (20-99 employees) & 0.35 & 0.48 \\
\hline Large firm (100+ employees) & 0.11 & 0.32 \\
\hline Main market is local & 0.58 & 0.49 \\
\hline Main market is domestic & 0.35 & 0.48 \\
\hline Main market is international & 0.07 & 0.25 \\
\hline Exporting firm & 0.16 & 0.37 \\
\hline Age of firm & 15.80 & 11.42 \\
\hline Domestic Firm & 0.05 & 0.22 \\
\hline Multiplant firm & 0.09 & 0.28 \\
\hline Construction Firm & 0.08 & 0.28 \\
\hline Manufacturing Firm & 0.41 & 0.49 \\
\hline Services Firm & 0.51 & 0.50 \\
\hline Firm located in capital or city $>1$ million & 0.31 & 0.46 \\
\hline Firm located in city with population $250 \mathrm{k}-1$ million & 0.25 & 0.43 \\
\hline Firm located in city with population $50 \mathrm{k}-250 \mathrm{k}$ & 0.15 & 0.36 \\
\hline Firm located in rural area & 0.28 & 0.45 \\
\hline
\end{tabular}

Source : BEEPS 2013

\section{Methodology}

The treatment-effect model employs a two-step production function approach, where firstly organisational HRM changes are the result of firm differences and secondly innovation outcomes are the result of organisational HRM changes and firm differences. The steps estimated in this paper are outlined in equations (1)-(5) below:

$$
Y_{i 0}=E\left(Y_{i 0} \mid X_{i}\right)+e_{i 0}
$$




$$
\begin{gathered}
Y_{i 1}=E\left(Y_{i 1} \mid X_{i}\right)+e_{i 1} \\
T_{i}=E\left(T_{i 0} \mid Z_{i}\right)+v_{i} \\
Y_{i}=T_{i} Y_{i 1}+\left(1-T_{i}\right) Y_{i 0} \\
E\left(e_{i j} \mid X_{i}, Z_{i}\right)=E\left(e_{i j} \mid Z_{i}\right)=E\left(e_{i j} \mid X_{i}\right)=0 \text { for } j \in\{0 \mid 1\}
\end{gathered}
$$

where, for firm i, $Y_{i 1}$ is the potential outcomes of new to firm $(\mathrm{NtF})$ product innovation or new to market $(\mathrm{NtM})$ product innovation when the firm employs an organisational HRM change, $Y_{i 0}$ is the potential outcome of $\mathrm{NtF}$ product innovation or $\mathrm{NtM}$ product innovation when an organisational HRM change is not employed. $T_{i}$ is the observed binary treatment of organisational HRM changes (as reported in Table 2 as management organisational change type and introduced in the previous 3 years as new or significantly improved for the first time) and $Y_{i}$ is the observed outcome. $Y_{i 0}$ and $Y_{i 1}$ are determined by its expected value conditional on a set of determinants $X_{i}$ and an error term $e_{i 0}$ for $j \in\{0 \mid 1\}$. The subsidy treatment is given by its expectation conditional on a set of determinants $Z_{i}$ and an error term $v_{i}$. The determinants for $X_{i}$ and $Z_{i}$ are: R\&D activity of the firm; firm size; the education of the workers; the industry type; the age of the firm; region and country dummies; principle operating market indicators; domestic or foreign firm indicators; multiplant and exporting firm indicators. $X_{i}$, also controls for a diversity of organisational HRM change measure ${ }^{2}$, so that ATE's can be compared across HRM types. Using equations (1) to (5), average treatment effects (ATE) are estimated by:

$$
A T E=E\left(Y_{1}-Y_{0}\right)
$$

Our key focus in this paper is to identify which organisational HRM changes are most beneficial for firm innovation ${ }^{3}$. We estimate the above six steps for all six HRM practices and another model for the general organisation variable ${ }^{4}$. The results of these seven models and the associated ATE are presented in Table 2. We now turn our attention to discussing the ATE differences from the organisational HRM changes on innovation in the next section.

\section{Results}

The ATE's presented in Table 2 illustrate that new or significantly improved organisational or management practices or structures are important for both $\mathrm{NtF}$ and $\mathrm{NtM}$ innovations. Furthermore, introducing any type of organisational HRM change has a positive effect on $\mathrm{NtF}$ and NtM product innovations. This finding supports the literature that HRM practices help explain the varied innovation performances that exist between firms (Tether et al. 2005; Toner 2011; Combs et al. 2006; Guest 2011; Arundel et al 2007).

While all organisational HRM changes positively influence innovation, it is also clear that some organisational changes are more important than others. The ATE's indicate the likelihood differences of introducing an organisational HRM change on $\mathrm{NtF}$ and $\mathrm{NtM}$ innovations vis-àvis a firm that does not introduce the organisational change, whilst controlling for other organisational changes introduced in the firm. New types of collaborations with other businesses, research organisations or consumers have the largest treatment effect on both $\mathrm{NtF}$ (0.227) and NtM (0.192) innovations. This finding is in line with previous studies which have

\footnotetext{
${ }^{2}$ Measured as the percentage of new or significantly improved HRM practices introduced in the firm, in the previous three years, for the first time.

${ }^{3}$ The determinants of treatment and potential outcomes are not the primary focus of this paper and therefore are not reported. These results are available from the authors on request.

${ }^{4}$ Estimation is Treatment effects with IPW regresssion adjustment. We use teffects ipwra command in STATA for doubly robust effects.
} 
shown the importance of collaboration for innovation activity (Love, Roper, and Bryson 2011; He and Wong 2012; Love and Roper 2004). Firms' willingness to partner with other organisations has been shown to be important at each stage of the innovation process (Love, Roper, and Bryson 2011). Collaborative working offers firms a potential route for accessing external skills, drawing on knowledge from a variety of sources to provide solutions to clients based on a combination of new and existing knowledge. Next in importance for innovation is outsourcing or subcontracting of business activities ( 0.220 for $\mathrm{NtF}$ and 0.148 for $\mathrm{NtM})$ - again indicating the importance of managing their portofolio of external relationships (Love and Roper 2001). Outsourcing activities can provide firms with economies of scope, as well as opportunities to secure the requisite capacity and capability to address new challenges. Significant changes to management structures is the third most important practice for innovation, with new knowledge management systems and management systems for production being less important. The least important organisational change for both types of innovation outcomes are new methods for distributing responsibilities and decision making among employees.

Table 2. The Average Treatment Effects (ATE) of Organisational HRM Changes and Innovation Outcomes.

\begin{tabular}{|c|c|c|}
\hline Organisational HRM Change Type & $N t F$ & $N t M$ \\
\hline $\begin{array}{l}\text { Organisation - During the last three years, has the } \\
\text { establishment introduced any new or significantly } \\
\text { improved organisational or management practices or } \\
\text { structures. }\end{array}$ & $0.293 * * *$ & $0.226 * * *$ \\
\hline $\begin{array}{l}\text { OHRM1 - New knowledge management systems to } \\
\text { better use or exchange information, knowledge and } \\
\text { skills within the establishment }\end{array}$ & $0.183 * * *$ & $0.126 * * *$ \\
\hline $\begin{array}{l}\text { OHRM2 -Introduction of management systems for } \\
\text { general production or supply operations, such as supply } \\
\text { chain management systems, lean production, business } \\
\text { reengineering, quality management systems }\end{array}$ & $0.133 * * *$ & $0.181 * * *$ \\
\hline $\begin{array}{l}\text { OHRM3 - New methods for distributing responsibilities } \\
\text { and decision making among employees }\end{array}$ & $0.103 * * *$ & 0.042 \\
\hline $\begin{array}{l}\text { OHRM4 - A significant change to the management } \\
\text { structure of the establishment, such as creating new } \\
\text { divisions or departments, integrating different } \\
\text { departments or activities }\end{array}$ & $0.191 * * *$ & $0.146 * * *$ \\
\hline $\begin{array}{l}\text { OHRM5 - New types of collaborations with other } \\
\text { businesses, research organisations or consumers }\end{array}$ & $0.227 * * *$ & $0.192 * * *$ \\
\hline $\begin{array}{l}\text { OHRM6 - Outsourcing or subcontracting of business } \\
\text { activities in production, procurement, distribution, } \\
\text { recruiting or ancillary services }\end{array}$ & $0.220 * * *$ & $0.148 * * *$ \\
\hline
\end{tabular}

Notes:

Variables with $* * *$ are significant at $1 \%$ level.

Standard errors are robust but not reported and are available from authors on request.

\section{Conclusions}

This paper finds that organisational changes have a positive disruptive effect on firm innovation outcomes. However, there is evidence of a hierarchy of HRM practices with some having a greater impact on innovation performance than others. The two most important organisational changes for innovation - collaboration and outsourcing- involve the firms' portofolio of external relationships, indicating that firms in emerging economies that wish to implement organisational changes to improve innovation outcomes should firstly focus on practices which 
engage external partners. Interestingly, a recent Swiss study on the relative importance of HRM practices for innovation reported that new workplace organisation practices were more important for firm innovation activities than other HRM practices such as flexible working pratcices, incentives and training (Arvanitis et al 2016). This indicates that variations may exist in terms of the most important organisation changes for innovation for different measures of innovation (e.g. innovation propensity vs. innovation success), different types of firms (e.g. manufacturing vs. services) and different economies (e.g. developed vs. emerging). More research examining the relative importance of HRM practices for innovation is needed to inform managerial and policy implications.

\section{References}

Abrunhosa, A. and Moura E Sá, P. (2008) Are TQM principles supporting innovation in the Portuguese footwear industry?, Technovation, 28, 208-221.

Arundel, A., Lorenz, E., Lundvall, B.Å. and Valeyre, A. (2007) How Europe's economies learn: a comparison of work organization and innovation mode for the EU-15, Industrial and Corporate Change, 16, 1175-1210.

Arvanitis, S., Seliger, F. and Stucki, T. (2016) The relative importance of human resource management practices for innovation, Economics of Innovation and New Technology, 25, 769-800.

Bank, E.W (2014) Business environment and enterprise performance survey, Enterprise Surveys (http://www.enterprisesurveys.org), The World Bank.

Bourke, J. and Crowley, F. (2015) The Role of HRM and ICT Complementarities in Firm Innovation: Evidence from Transition Economies, International Journal of Innovation Management, 19.

Combs, J., Liu, Y.M., Hall, A. and Ketchen, D. (2006) How much do high-performance work practices matter? A meta-analysis of their effects on organizational performance, Personnel Psychology, 59, 501-528.

Crowley, F. and Bourke, J. (2016) The Influence of Human Resource Management Systems on Innovation: Evidence from Irish Manufacturing and Service Firms, International Journal of Innovation Management, 20.

Cuijpers, M., Guenter, H. and Hussinger, K. (2011) Costs and benefits of inter-departmental innovation collaboration, Research Policy, 40, 565-575.

Gibson, C.B. and Gibbs, J.L. (2006) Unpacking the concept of virtuality: the effects of geographic dispersion, electronic dependence, dynamic structure, and national diversity on team innovation, Administrative Science Quarterly, 51, 451-495.

Gordon, N.R. and McCann, P. (2005) Innovation, agglomeration, and regional development, Journal of Economic Geography, 5, 523-543.

Guest, D.E. (2011) Human resource management and performance: still searching for some answers, Human Resource Management Journal, 21, 3-13.

He, Z.L. and Wong, P.K. (2012) Reaching Out and Reaching Within: A Study of the Relationship between Innovation Collaboration and Innovation Performance, Industry and Innovation $19,539-561$.

Hewitt-Dundas, N. (2004) The adoption of AMT and innovation strategy in small firms, International Journal of Innovation and Technology Management, 1, 17-36.

Laursen, K. and Foss, N.J. (2003) New human resource management practices, complementarities and the impact on innovation performance, Cambridge Journal of Economics, 27, 243-263. 
Laursen, K., Mahnke, V. and Vejrup-Hansen, P. (2005) Do differences make a difference? The impact of human capital diversity, experience and compensation on firm performance in engineering. In Druid Working Paper, Series 5.

Love, J.H. and Roper, S. (2001) Outsourcing in the innovation process: Locational and strategic determinants. Papers in Regional Science 80, 317-336. 2004. The Organisation of Innovation: Collaboration, Cooperation and Multifunctional Groups in UK and German Manufacturing. Cambridge Journal of Economics, 28, 379-395.

Love, J.H., Roper, S. and Bryson, J.R. (2011) Openness, knowledge, innovation and growth in UK business services, Research Policy, 40, 1438-1452.

Love, J.H., Roper, S. and Du, J. (2009) Innovation, Ownership and Profitability, International Journal of Industrial Organization.

Mansury, M.A. and Love, J.H. (2008) Innovation, productivity and growth in US business services: a firm-level analysis, Technovation, 28, 52-62.

Michie, J. and Sheehan, M. (2003) Labour market deregulation, 'flexibility' and innovation, Cambridge Journal of Economics, 27, 123-143.

Romer, P.M. (1990) Endogenous Technological Change, Journal of Political Economy, 98, S71-S102.

Roper, S., Hewitt-Dundas, N. and Love, J.H. (2004) An Ex Ante Evaluation Framework for the Regional Benefits of Publicly Supported R\&D Projects, Research Policy, 33, 487-509.

Santos-Vijande, M.L. and Álvarez-González, L.I. (2007) Innovativeness and organizational innovation in total quality oriented firms: The moderating role of market turbulence, Technovation, 27, 514-532.

Tether, B., Mina, A., Consoli, D. and Gagliardi, D. (2005) A Literature Review on Skills and Innovation. How Does Successful Innovation Impact on the Demand for Skills and How Do Skills Driven Innovation?, in University of Manchester: ESRC Centre on Innovation and Competition.

Todnem By, R. (2005) Organisational change management: A critical review, Journal of Change Management, 5, 369-380.

Toner, P. (2011) Workforce skills and innovation - an overview of major themes in the literature. In STI Working Paper ed. T.a.I.S. OECD Directorate for Science, Paris: OECD. 